\title{
OPTIMIZATION OF TRANSPORT PROCESSES IN SUPPLY CHAINS OF EPICENTER HYPERMARKET NETWORK
}

\section{O. M. Zagurskiy, T. S. Zhurakovska}

National University of Life and Environmental Sciences of Ukraine, Ukraine.

Speciality of article: 275 - transport technologies (by road).

Corresponding authors: zagurskiy_oleg@ukr.net.

Article history: Received-April 2020, Accepted-August 2020.

Bibl. 18, fig. 3, tabl. 0 .

Abstract. Negative changes in the environment, leading to public pressure and environmental legislation require fundamental changes in the industrial practice of business. Survey of the environment in 22 countries found that: in half of the countries surveyed, the environment is considered to be one of the three most serious problems of concern to society. In most countries, the overwhelming number of citizens surveyed indicated that the state of the environment had an impact on their health, and an even larger proportion stated that the environment had an impact on the health of their children.

The article deals with the problem of increasing the level of environmental friendliness of transportation in supply chains. With the modern requirements in the integrated green supply chain, the reduction of the harmful impact of production and logistics activities on nature should be considered at all stages of the technological cycle of product development and its promotion through the supply chain.

It is determined that the key technologies for reducing the anthropogenic impact on the environment are the optimization of transport processes due to the reduction of distance during transportation at all stages of the supply chain; the increase in the use of local resources (reducing fuel costs and harmful emissions); the use of modern environmentally friendly energy-efficient vehicles.

The basic principles and approaches of the consolidated cargo transportation model have been substantiated, which balances environmental and economic problems and their testing has been carried out in the supply chain of the Epicenter hypermarket chain.

Key words: economy, environmental friendliness, supply chain, routing, optimization, harmful emissions.

\section{Introduction}

Negative changes in the environment, leading to public pressure and environmental legislation require fundamental changes in the industrial practice of business. For example, a survey of the environment in 22 countries found that: in half of the countries surveyed, the environment is considered to be one of the three most serious problems of concern to society. In most countries, the overwhelming number of citizens surveyed indicated that the state of the environment had an impact on their health, and an even larger proportion stated that the environment had an impact on the health of their children. In 16 out of 22 countries, citizens have stated that they are avoiding products that harm the environment. Under these conditions, the local and direct impact of products and processes on nature can no longer be considered acceptable or cost-effective; there is a need for a comprehensive analysis of the lifecycle goals of all products and processes and for improving their environmental friendliness.

\section{Formulation of problem}

Accordingly, the number of organizations planning to integrate environmental practices into their strategic plans and daily operations is steadily increasing. Regulatory requirements and consumer pressure drive the development of green supply chains (GrSCM) forward. Now their scope varies from monitoring of general environmental management programs to more biased practices through various "green" processes in production (reuse, recycling, recovery, reverse logistics, etc.).

\section{Analysis of recent research results}

Overseas scholars have conducted a wide range of studies on various aspects and problems of GrSCM application: Bektas, T., Laporte, G. (2011) [4], Chaabane A., Ramudhin A., Paquet M., (2012) [5], Christof, Dr., \& Ehrhart, E. (2012) [6], Dekker R., Bloemhof J., Mallidis I. (2012) [7], McKinnon, A., Cullinane, S., Whiteing, A., \& Browne, M. (2010) [12], Zhuravskaya M. (2016) [17].

The issues of inclusion of ecological component in the system of logistic management are considered in the works of Ukrainian Scientists N. Margita, U. Bilonizhka [1], O. Mnykh, B. Grechina [2] O. Zagurskiy, S. Rogach, L. Titova, I. Rogovskii, T. Pokusa [16] and some others [18]. 


\section{Purpose of research}

The goal of the work is to substantiate the basic approaches of the model of transportation of consolidated cargoes, which balances environmental and economic problems and its testing in the supply chain of the Epicenter hypermarket network.

\section{Results of research}

Experience in carrying out lifting works testifies that Modern researchers are looking at reducing the adverse impact of production and logistics activities on the natural spheres at all stages of the product cycle and supply chain links. And virtually all of them agree that the "green" supply chain is a supply chain in which at least several units use "green" (environmentally friendly) technology. Basically, we are talking about "green" production or purchasing, and there are practically no works on "green" transportation of goods. Suppliers, manufacturers, and customers associated with the supply chain may be neglected at short distances from each other by environmentally harmful transport.

However, if the transportation process takes a significant share in the total volume of supply chain logistics operations, even in the presence of green production, procurement and sales oriented on ecomarketing, then this chain is not considered to be green, in our view.

After all, according to experts, transport accounts for about $14 \%$ of the total carbon dioxide emissions on the planet, for storage facilities another 3\% [14]. Transportation is also a major source of NOx, SOx, and particulate matter or fine dust [15]. In this regard, the introduction of "green" technologies in the logistics activities will make a significant contribution to maintaining the climate on the planet suitable for human life.

The urgent need to reduce the adverse effects of transport and logistics activities on the environment has led economically developed countries to taking decisive action. In 1994, the European Parliament and the Council introduced the Directive 94/62 / EC of the European Parliament and of the Council on packaging and packaging waste, which at the legislative level obliges companies to increase the use of reusable containers, to process waste from production and logistics activities, to introduce packaging management systems. [9].

At the municipal level, cities and regions of EU countries make decisions to ban the movement of old and, in some cases, new generation diesel vehicles in European cities. So, in Germany, after suing Deutsche Umwelthilfe, it was forbidden to enter certain streets for diesel and gasoline vehicles of old models in Stuttgart, Hamburg, Berlin, Cologne, Bonn, Frankfurt am Main and some other cities. These are diesel vehicles with Euro 4 and Euro 5 environmental standards. Moreover, the governments of Denmark and Ireland plan to ban diesel and gasoline vehicles from 2030 altogether [8].

It should be noted that the principles of green logistics are widely promoted by the European Logistics Association, which conducts a European ranking of logistic projects annually. In 2012, the Green Freight Europe (Green Freight Europe) project was launched, initiated by shippers and logistics companies, with the aim of developing a unified approach to identifying the emission factors and comparing the environmental parameters of different transport operators.

In science, the beginning of the development of "green" logistics in 1989 was provided by the German scientist E. Müller, who also proposed the term "green logistics" (from English green logistics). Together with his colleagues, he paid great attention to transport logistics, noting the strong link between logistics, environmental protection and natural resources. Later, scientists at Dresden Technical University continued their research and examined the relationship between business and the environment.

The urgency of considering this issue by scientists emerged along with the emergence of the concept of "social responsibility of business", which is inherent in the duality and dialectical unity of contradictions. Indeed, social responsibility, on the one hand, is an intrinsic motivation, an innate and acquired capacity that gives the actions a socially considered, socially significant, spiritual and moral character.

On the other hand, social responsibility emerges as an institution that provides for sanctions for socially inappropriate actions or for inaction. From these positions, research from foreign scientific sources has made it possible to distinguish the interpretation of "green" logistics, which scientists most often rely on.

Thus, according to P. Murphy, R. Braunschweig and D. Charles "green" logistics directs standard logistical requirements for the rationality, efficiency and speed of processing and movement of goods, and takes into account environmental measures" [13]. Within this concept, logistic activity is limited to a transport system of distribution that must be carried out on environmental principles.

Logistics has traditionally been the planning, execution and control of the movement and placement of people and/or goods within the economic system to achieve certain goals [10]. And if the main function of traditional logistics is to coordinate all types of logistics activities to meet the needs of customers with minimal cost, then in green logistics, companies pay more attention to external externalities related to climate change, air, water and soil pollution in order to achieve sustainable balance between economy, environment and society [11]. The basic principles of environmental logistics include environmentally safe transportation and storage of material resources [3].

If we consider transport separately, the key tasks to reduce the harmful effects of transport on the environment will be:

- reducing the harmful effects of transport on human health by reducing the amount of impacts, emissions and discharges, the amount of waste on all modes of transport (training and streamlining of routes);

- reduction of energy consumption of transport;

- motivation for the transition of vehicles to environmentally friendly fuels.

Solving certain tasks is directly related to the significant financial costs that consumers are not always 
ready to compensate. So, one of the most important issues in green logistics is balancing environmental and business (economic) issues. Improving the environment is expensive, so the question is what trade-offs arise between the consequences of economic activity and its value, and what solutions can balance environmental and economic problems? That is to say, the main task in this area is to identify solutions in which, at constant costs, environmental damage only decreases. Such solutions are called environmental.

Among them, an important transport concept in terms of environmental friendliness is "Vehicle Routing and Planning (VRSP)", i.e. the search for the most optimal routes and means of transportation of goods.

In this concept, the process of optimizing the supply chain can be represented as finding the best option for the functioning of the supply chain from the many possible. In order for the supply chain optimization process to take place, it is necessary to clearly understand what and how to achieve the end result, i.e. a "perfect" model, once created and tested in managing other supply chains (best practice methodology), or designed in "laboratory" conditions, to which the parameters must be sought. An "ideal" supply chain model assumes the existence of a single information system that manages orders based on the fact that:

- the time of the order fulfillment cycle should be minimal in terms of deviations from the terms stated by the customer (ideally zero);

- the amount of inventory in the supply chain should be minimal (ideally zero);

- the impact of the human factor must be minimal;

- the use of environmentally-friendly transportation technologies should be maximized.

Depending on the desired results, each optimization has its own separate goals. In the supply chain of the Epicenter hypermarket chain we have studied, the transport process has been optimized in such a way that symbiosis of efficient, economic and environmental transportation of products has occurred.

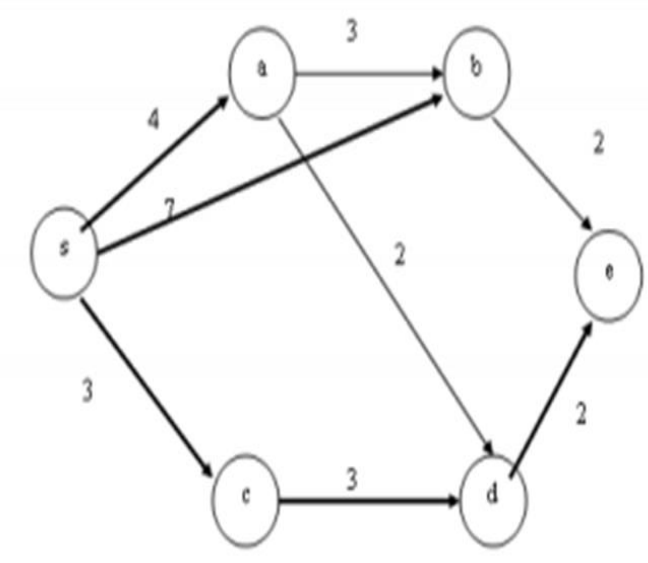

Fig. 1. Optimized schedule of deliveries of goods to Epicenter stores in Kyiv.

Technological operations during the execution of It should be noted that such a supply option is possible and entitled to life. It significantly reduced the time and distance of supply, with all customers satisfied. However, this decision is not the only one. The shortest path is only possible if there is no ambiguity in the choice of arcs in the algorithm. In this example, such ambiguity has arisen and accordingly there is an alternative solution:

$$
(\mathrm{s}, \mathrm{e})=\{(\mathrm{s}, \mathrm{a}),(\mathrm{a}, \mathrm{d}),(\mathrm{d}, \mathrm{e})\}
$$

That is to say, to fully implement the "ideal" model in the practice of the transport company "Epicenter" is quite difficult. This is because it fails to accurately reproduce all the conditions in which the "ideal" model of another supply chain operates, and, moreover, it is impossible to embody a specially created "ideal" model, since it cannot take into account all real, and constantly changing, parameters of external and internal business environment.

Therefore, in order to get as close as possible to the parameters of the desired "ideal" supply chain model, it is necessary to be able to respond quickly and effectively to increasingly complex consumer requests, but without losing the idea of achieving the goals of balancing costeffectiveness and environmental friendliness.

However, the Vehicle Routing and Planning (VRSP) problem is only about identifying routes and schedules for a fleet of vehicles to meet the demands of many customers. Reducing the overall distance of transportation itself will undoubtedly provide environmental benefits by reducing the consumption of fuel and pollutants.

However, the relationship between routing and vehicle emissions is not so straightforward. For example, the time spent in traffic jams by a vehicle with a cold engine can have a significant impact on environmental pollution.

Another solution to the problem of improving the environmental performance of transportation is to consolidate, especially when transporting goods in small lots ("Less-Than-Truckload" (LTL). In this case, when it goes about long-distance transportation, smaller lots are combined with larger ones to achieve both economic and environmental efficiency.

The inclusion of intermediate transshipment points in this system, which will move goods from large trucks to environmentally friendly urban trucks, will further improve the quality of environmental management in transportation. In addition, consolidation efficiency can also be achieved by combining transportation from different suppliers to neighboring stores, i.e. the use of car-sharing systems, such as modifying business thinking and facilitating the economic benefits of creating an integrated "green" supply chain.

Combining certain approaches, the task of building a transportation model is to optimize the routing of a fixedcapacity vehicle fleet to deliver consolidated cargo over a period of time. Optimization is determined by finding a solution that minimizes the number of cars used and the total travel time.

Travel time is calculated knowing the time of departure and an accurate estimate of the average speed of the car when driving on a certain route ( $\operatorname{arc})$. Thus, minimizing the total travel time, the resulting solutions will direct vehicles to roads on which they can move quickly instead of standing in traffic jams.

For the supply chain of the Epicenter hypermarket chain, the transport pattern for a certain model may take the following form (Figure 2). 


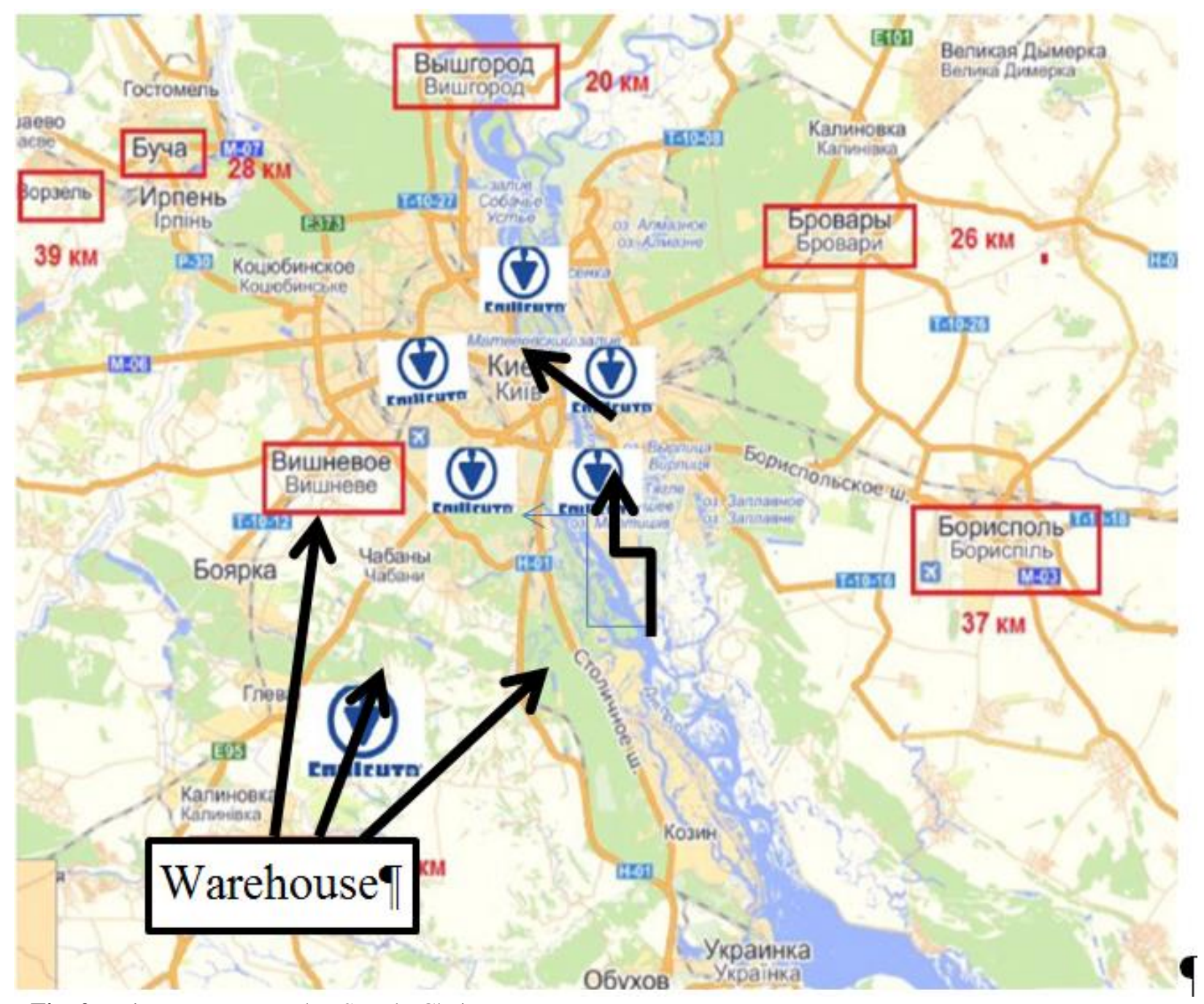

Fig. 2. EpicenterHypermarket Supply Chain.

However, when it comes to time constraints such as delivery time scales for customers, optimal solutions known for the classic case become unworkable and the degree of impracticability increases with the variability of traffic conditions. So, the added benefit of this approach is that it allows you to more reliably perform timewindow constraints. For a time-dependent model, travel time may also depend on other factors, such as day of the week or time of the year.

\section{Conclusions}

1. With the modern requirements in the integrated green supply chain, the reduction of the harmful impact of production and logistics activities on nature should be considered at all stages of the technological cycle of product development and its promotion through the supply chain.

2. From the point of view of transport logistics directly, the key technologies for reducing the anthropogenic impact of transport on the environment are the optimization of transport processes and networks, namely:

- the reduction of distance during transportation at all stages of the supply chain;
- the increase in the use of local resources (reducing fuel costs and harmful emissions);

- the use of modern environmentally friendly energyefficient vehicles.

3. This optimization should bring the company a triple benefit: reducing environmental load, improving image and reducing costs across the supply chain.

4. To ensure the efficient functioning of the Epicenter hypermarket network, the logistics system must be represented by the ratio of not one, but the complex of the results of such a system to the costs of its operation, and therefore methods that require multicriteria evaluation of the efficiency of the logistics system by the criteria of "cost", " consumer satisfaction/quality", "time", "assets","technology".

\section{References}

1. Margita N. O., Belonizhka U. Z. (2014). Current tendencies of implementation of green logistics. Marketing and innovation management. 1. 279-286.

2. Mnykh O. B., Grechin B. D. (2016). Strategic role of ecology in enterprise development in conditions of deepening ecological crisis in Ukraine. Economic analysis. 2. 108-118. 
3. Elyashevich I. P., Elyashevich E. R. (2011). Prospects for the development of environmental logistics in Russia. Logistics and Supply Chain Management.

4. Bektas T., Laporte G. (2011). The pollutionrouting problem. Transportation Research B: Methodological. 45(8). 1232-1250.

5. Chaabane A., Ramudhin A., Paquet M. (2012). Design of sustainable supply chains under the emission trading scheme. International Journal of Production Economics. 135(1). 37-49.

6. Christof Dr., Ehrhart E. (2012). Delivering Tomorrow: Towards Sustainable Logistics. Bonn, Germany: Deutsche Post AG. Retrieved from http://www.delivering-tomorrow.com.

7. Dekker R., Bloemhof J., Mallidis I. (2012). Operations Research for green logistics - An overview of aspects, issues, contributions and challenges. European Journal of Operational Research. 219. 671-679.

8. Denmark to ban petrol and diesel car sales by 2030. URL: https://www.euractiv.com/section/electriccars/news/denmark-to-ban-petrol-and-diesel-car-sales-by2030.

9. Fernier J., Sparks L., McKinnon A. C. (2010). Retail Logistics in the UK: Past, Present and Future. International Journal of Retail Logistics \& Distribution Management. 38. 11/12. 894-914.

10. Gleissner H., Femerling J. C. (2013). Logistics: Basics-Exercises-Case Studies. Cham, Hei- delberg. New York, Dordrecht, London: Springer. 210.

11. Green Logistics URL: http://www.greenlogistics. org.

12. Kinnon A., Cullinane S., Whiteing A., Browne M. (2010). Green logistics: Improving the environmental sustainability of logistics. India: Replika Press Pvt Ltd. 426.

13. Murphy P. R., Braunschweig R. F., Charles D. (1996). Green logistics: Comparative views of environmental progressives, moderates, and conservatives. Journal of Business Logistics. URL: http:// findarticles.com/p/articles/mi_qa3705/is_199601/ai_n874 8499.

14. Palanivelu P., Dhawan M. (2010). Green Logis tics. TCS. URL: http://www.tcs.com/Site Collection Do cuments/White\%20Papers/CPG_WhitePaper_Green_Lo gis tics_08_2010.pdf.

15. Piecyk M., McKinnon A. (2010). Forecasting the carbon footprint of road freight transport in 2020. International Journal of Production Economics. 128. 3142.

16.Zagurskiy O., Rogach S., Titova L., Rogovskii I., Pokusa T. (2019). «Green» supply chain as a path to sustainable development. Mechanisms of stimulation of socio-economic development of regions in conditions of transformation. Monograph. Opole: The Academy of Management and Administration in Opole. 199-213.

17. Zhuravskaya M. (2016). Green Logistics as the basis for Improving Environmental Efficiency of Transport. EcoProduction. Efficiency in Sustainable supply chain : Springer Verlag, Berlin Heidelberg. 25.

18. Zagurskiy O., Ohiienko M., Pokusa T., Zagurska S., Pokusa F., Titova L., Rogovskii I. (2020). Study of efficiency of transport processes of supply chains management under uncertainty. Monograph. Opole: The
Academy of Management and Administration in Opole. 162.

\section{Список літератури}

1. Margita N. O., Belonizhka U. Z. Current tendencies of implementation of green logistics. Marketing and innovation management. 2014. Vol. 1. P. 279-286.

2. Mnykh O. B., Grechin B. D. Strategic role of ecology in enterprise development in conditions of deepening ecological crisis in Ukraine. Economic analysis. 2016. Vol. 2. P. 108-118.

3. Elyashevich I. P., Elyashevich E. R. Prospects for the development of environmental logistics in Russia. Logistics and Supply Chain Management. 2011. 126 p.

4. Bektas T., Laporte $G$. The pollution-routing problem. Transportation Research B: Methodological. 2011. Vol. 45(8). P. 1232-1250.

5. Chaabane A., Ramudhin A., Paquet M. Design of sustainable supply chains under the emission trading scheme. International Journal of Production Economics. 2012. Vol. 135(1). P. 37-49.

6. Christof Dr., Ehrhart E. Delivering Tomorrow: Towards Sustainable Logistics. Bonn, Germany: Deutsche Post AG. 2012. Retrieved from http://www.delivering-tomorrow.com.

7. Dekker R., Bloemhof J., Mallidis I. Operations Research for green logistics - An overview of aspects, issues, contributions and challenges. European Journal of Operational Research. 2012. Vol. 219. P. 671-679.

8. Denmark to ban petrol and diesel car sales by 2030. URL: https://www.euractiv.com/section/electriccars/news/denmark-to-ban-petrol-and-diesel-car-sales-by2030.

9. Fernier J., Sparks L., McKinnon A. C. Retail Logistics in the UK: Past, Present and Future. International Journal of Retail Logistics \& Distribution Management. 2010. Vol. 38. Issue 11/12. P. 894-914.

10. Gleissner H., Femerling J. C. Logistics: BasicsExercises-Case Studies. Cham, Hei- delberg. New York, Dordrecht, London: Springer, 2013. 210 p.

11. Green Logistics URL: http://www.greenlogistics. org.

12. Kinnon A., Cullinane S., Whiteing A., Browne M. Green logistics: Improving the environmental sustainability of logistics. India: Replika Press Pvt Ltd. 2010. 426 p.

13. Murphy P. R., Braunschweig R. F., Charles D. Green logistics: Comparative views of environmental progressives, moderates, and conservatives. Journal of Business Logistics. 1996. URL: http:// findarticles. com/p/articles/mi_qa3705/is_199601/ ai_n874 8499.

14. Palanivelu P., Dhawan M. Green Logis tics. TCS. 2010. URL: http://www.tcs.com/Site Collection Do cuments/White\%20Papers/CPG_WhitePaper_Green_Lo gis tics_08_2010.pdf.

15.Piecyk M., McKinnon A. Forecasting the carbon footprint of road freight transport in 2020. International Journal of Production Economics. 2010. Vol. 128. P. 3142. 
16.Zagurskiy O., Rogach S., Titova L., Rogovskii I., Pokusa T. «Green» supply chain as a path to sustainable development. Mechanisms of stimulation of socioeconomic development of regions in conditions of transformation. Monograph. Opole: The Academy of Management and Administration in Opole. 2019. P. 199213.

17. Zhuravskaya M. Green Logistics as the basis for Improving Environmental Efficiency of Transport. EcoProduction. Efficiency in Sustainable supply chain : Springer Verlag, Berlin Heidelberg. 2016. 25 p.

18. Zagurskiy O., Ohiienko M., Pokusa T., Zagurska S., Pokusa F., Titova L., Rogovskii I. Study of efficiency of transport processes of supply chains management under uncertainty. Monograph. Opole: The Academy of Management and Administration in Opole. 2020. 162 p.

\section{ОПТИМІЗАЦІЯ ТРАНСПОРТНИХ ПРОЦЕСІВ В ЛАНЦЮГАХ ПОСТАЧАНЬ МЕРЕЖІ ГІПЕРМАРКЕТІВ «ЕПІЦЕНТР»}

О. М. Загурський, Т. С. Жураковська

Анотація. Негативні зміни в стані навколишнього середовища, що призводять до тиску 3 боку громадськості та екологічне законодавство вимагають фундаментальних зміни у виробничій практиці бізнесу. Обстеження стану навколишнього середовища в 22 країнах світу показало, що: у половині обстежених країн довкілля вважається однією 3 трьох найбільш серйозних проблем, що турбують суспільство.

В статті розглянуто проблему підвищення рівня екологічності тарнспортних перевезень в ланцюгах постачань. За сучасних вимог у інтегрованому «зеленому» ланцюзі постачань зменшення шкідливого впливу виробничо-логістичної діяльності на природу має розглядатися на усіх етапах технологічного циклу вироблення продукту та його просування по ланках постачання.

Визначено, що ключовими технологіями для зниження антропогенного впливу на навколишне середовище $\epsilon$ оптимізація транспортних процесів через зниження відстані при перевезенні вантажів на всіх стадіях ланцюга постачань; збільшення використання локальних ресурсів (скорочення витрат на паливо і шкідливі викиди в атмосферу); застосування сучасних екологічних енергозберігаючих транспортних засобів.

Обгрунтувано основні принципи і підходи моделі перевезень консолідованих вантажів, що збалансувує екологічні й економічні проблеми та проведено їх апробацію в ланцюзі постачань мережі гіпермаркетів «Епіцентр».

Ключові слова: економічність, екологічність, ланцюг постачань, маршрутизація, оптимізація, шкідливі викіди.

\section{ОПТИМИЗАЦИЯ ТРАНСПОРТНЫХ ПРОЦЕССОВ В ЦЕПЯХ ПОСТАВОК СЕТИ ГИПЕРМАРКЕТОВ «ЭПИЦЕНТР» \\ О. Н. Загурский, Т. С. Жураковская}

Аннотация. Негативные изменения в состоянии окружающей среды, приводящие к давлению со стороны общественности и экологическое законодательство требуют фундаментальных изменения в производственной практике бизнеса. Обследование состояния окружающей среды в 22 странах мира показало, что: в половине обследованных стран состояние окружающей среды относится одной из трех самых серьезных проблем, которые волнуют общество.

В статье рассмотрена проблема повышения уровня экологичности тарнспортних перевозок в цепях поставок. При современных требованиях к интегрированной «зеленой» цепи поставок уменьшение вредного влияния производственнологистической деятельности на природу должно рассматриваться на всех этапах технологического цикла производства продукта и его продвижение по звеньям поставки.

Определено, что ключевыми технологиями для снижения антропогенного воздействия на окружающую среду является оптимизация транспортных процессов через снижение расстояния при перевозке грузов на всех стадиях цепи поставок; увеличение использования локальных ресурсов (сокращение расходов на топливо и вредные выбросы в атмосферу); применения современных экологических энергосберегающих транспортных средств.

Обосновано основные принципы и подходы модели перевозок консолидированных грузов, которые балансируют экологические и экономические проблемы. Проведено их апробацию в цепи поставок сети гипермаркетов «Эпицентр».

Ключевые слова: экономичность, экологичность, цепь поставок, маршрутизация, оптимизация, вредные выброса.

О. М. Загурський ORCID 0000-0002-5407-8466. T. С. Жураковська ORCID 0000-0001-8795-7267. 